in which Haliday's notes were written.

In 1967 he presented to the Smithsonian Institution, Washington, his vast collection of 90,000 beautifully mounted insects because no other museum had so many specialists in the subject. The types of the many species new to science described by him are in this collection.

In the early 1900 s he was one of the dedicated group who rased the status of the Irish Field Clubs to their highest level. $\mathrm{He}$ was editor of the Irish Naturalist for years and an adviser and copious contributor to the Irish Naturalists' Journal until his death.

He studied the skeletons of birds and small animals found in cave deposits and became so proficient he could identify most species of birds from only two bones. His knowledge of surface geology made any drive with him memorable.

Together with his wife who was also a botanist, he kept open house wherever he resided and especially welcomed the younger generation. His dedication to natural history left no time for public or social engagements but its benefit to present and future naturalists is inestimable.

[Reprinted from the Irish Times

\section{Professor Harusada Suginome}

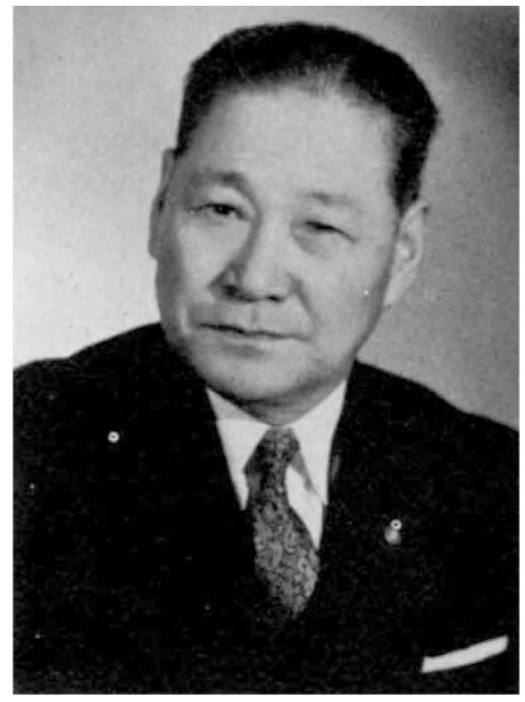

Harusada Suginome, Chairman of the Japanese National Commission for UNESCO, died on April 14, 1972, in Sapporo, Japan, aged 79. With his death Japan has lost not only a distinguished organic chemist but also a staunch worker in the cause of international scientific cooperation.

Born in Sendai, the old traditional city in the north-eastern district of the Japanese mainland, Suginome graduated from Tohoku University to work with the late Professor Rikoh Majima on the chemistry of aconite alkaloids, a group of very toxic substances. In 1925 he was the first Japanese recipient of a Rockefeller scholarship for studying abroad, and he became a collaborator of Sir Robert Robinson's in the Department of Organic Chemistry at the University of Manchester, where he remained until 1927. His research in Manchester was concerned with indolenine in connexion with the synthesis of physostigmine (eserine). During his stay in England he became an ardent anglophile and a life member of the London Chemical Society.

After his return to Japan in 1928 he became Professor of Organic Chemistry in the newly created Faculty of Science, Hokkaido University, at Sapporo in 1930. He continued his fundamental studies of aconite alkaloids, which were a poorly understood group of complex natural products at that time, and initiated work on veratrum alkaloids and carotenoids although the great shortage of equipment and chemicals during and immediately after the Second World War created severe difficulties for his research. In spite of this Suginome was nevertheless able to make significant contributions to the isolation and structural elucidation of aconite alkaloids. For this distinguished work, he received the Hattori Hohkokai Prize (1950) and the award of the Chemical Society of Japan (1951), of which he became president in 1967. In 1954, after four fruitful years as Dean of the Faculty of Science, he was elected President of Hokkaido University, a position he held until 1966. During this period he devoted much of his attention to educational affairs and expansion of the university.

Suginome also took an active part in public affairs and he regarded it as his duty to contribute to the development of Hokkaido, serving as President of the Hokkaido District Government Council for Science and Technology and as Chairman of the Committee for Development of Hokkaido as well as on other committees associated with the district government. As a firm believer that the public should be properly informed on scientific matters, he was chosen to be a member of the Managing Committee of the Japan Broadcasting Corporation (NHK), and from 1966 until his death he served on the Council for Science and Technology of Japan.

But it was in the field of international cooperation that Suginome's chief contribution was made in his later years. $\mathrm{He}$ visited the United Kingdom, the United States and many other countries, often as chairman of delegations, promoting the cause of international scientific understanding, and in 1961 he was selected as a member of the JapanUnited States Committee on Scientific Cooperation. In 1966 he became the first president of the British-Japanese Society in Hokkaido and the Japanese representative to the Japan-United States Committee on Cultural and Educational Cooperation. In 1971 he became the first president of the UNESCO Asian Cultural Centre.

In recognition of his many achievements, His Majesty the Emperor conferred on him the First Class of the Order of the Sacred Treasure in 1967.

A gentle unassuming man, Suginome nevertheless stood firm by ideas and ideals in which he believed. International science will be the poorer for his death.

\section{Announcements}

\section{International Meetings}

August 2-4, Applications of X-ray Analysis, Denver (Dr C. O. Ruud, Metallurgy and Materials Sciences Division, Denver Research Institute, University of Denver, Colorado 80210, USA).

August 7-11, Atomic Physics, Boulder (S. J. Smith, Joint Institute for Laboratory Astrophysics, University of Colorado, Boulder, Colorado 80302, USA).

August 7-14, Biophysics, Moscow (Secretary-General, Fourth International Biophysics Congress, Profsoyuznaya 7. Moscow V-133, USSR)

August 9-11, Reindeer/Caribou, Fairbanks, Alaska (R. G. White, Institute of Arctic Biology, University of Alaska, Fairbanks, Alaska 99701, USA).

August 13-17, Biology of the Seal, Guelph (Professor K. Ronald, College of Biological Sciences, University of Guelph, Guelph, Canada).

August 14-18, Physics and Chemistry of Ice, Ottawa (M. K. Ward, National Research Council of Canada, Montreal Road, Ottawa 7, Canada).

August 14-18, Numerical Analysis, Dublin (Dr J. Miller, School of Mathematics, Trinity College, Dublin 2, Ireland).

August 14-18, ANZAAS Congress, Sydney (ANZAAS Congress Executive Officer, University of New South Wales, PO Box 1, Kensington, NSW, Australia). August 14-18, Cosmochemistry, Cambridge, Massachusetts (Professor A. G. W. Cameron, Belfer Graduate School of Science, Yeshiva University, Amsterdam Avenue and 186th Street, New York, NY 10033, USA).

August 15-18, International Primatological Society Congress, Portland, Oregon (Dr William Montagna, ORPRC, 505 NW 185th Avenue, Beaverton, Oregon 97005, USA).

August 16-19, Strontium Metabolism, Glasgow (Dr J. M. A. Lenihan, Department of Clinical Physics and Bioengineering, Western Regional Hospital Board, 11 West Graham Street, Glasgow G4 9LF). 